\title{
PERLINDUNGAN HUKUM PREVENTIF TERHADAP EKSPRESI BUDAYA TRADISIONAL DI DAERAH ISTIMEWA YOGYAKARTA BERDASARKAN UNDANG-UNDANG NOMOR 28 TAHUN 2014 TENTANG HAK CIPTA
}

\author{
Dr. Dyah Permata Budi Asri., S.H., M.Kn \\ Dosen Fakultas Hukum Universitas Janabadra Yogyakarta
}

Contact: dyah@janabadra.ac.id

Diterima: 29 Juni 2018

Direvisi: 14 Agustus 2018

Disetujui: 15 Agustus 2018

Hak Cipta: (C) 2018

Halaman: 13 - 23

\begin{abstract}
This research aims to get an overview of the legal protection of traditional cultural expressions in the Yogyakarta that will maintain several cultures from ownership claims by other parties or other nations. For this reason, efforts are needed so that the culture can be preserved from destruction and loss of culture due to claims of ownership by other parties. This research is a normative juridical research that takes data in the field as primary material. The result of this study is to protect against traditional cultural expressions which are communal, which is very different from the general intellectual property regime such as song copyrights, marks, patents which are very individualistic. The regulation regarding its proper protection component is carried out by using preventive protection as practiced by the Department of Culture of the Yogyakarta Province and the Culture and Tourism Office of Sleman Regency, namely by conducting cultural inventory and documentation, as mandated in Law Number 28 of 2014 concerning Copyright especially Article 38. Recording of non-material cultural heritage is considered important because some elements of cultural heritage do not begin to be threatened with extinction or potentially claimed ownership by other countries. Until 2016, 444 intangible cultural works were registered as Indonesian Intangible Cultural Heritage managed by the Directorate General of Culture, Ministry of Education and Culture. While the Yogyakarta Department of Culture has attempted to carry out an inventory of several cultures in Yogyakarta. There are 22 (twenty-two) cultural works recorded in Yogyakarta that have been designated as intangible cultural heritage of Indonesia.
\end{abstract}

Kata Kunci: Protection, Expression Tradional Culture, Preventif, Inventory, Documentation

\section{PENDAHULUAN}

Daerah Istimewa Yogyakarta selanjutnya disebut Yogyakarta, merupakan daerah destinasi pariwisata ke tiga setelah Bali dan DKI Jakarta. (BPS, 2014). Hal ini dikarenakan keanekaragaman upacara adat dan budaya serta didukung oleh kreativitas seni dan keramahtamahan masyarakat, sehingga membuat Yogyakarta mampu menciptakan produk-produk budaya dan pariwisata yang beraneka ragam.

Salah satu sektor andalan Yogyakarta adalah Pariwisata yang berbasis kebudayaan. Beragamnya obyek dan daya tarik wisata telah banyak menyerap wisatawan baik domestik maupun mancanegara. Dari data yang ada pada Dinas Pariwisata Propinsi DI Yogyakarta, tahun 2015 lalu kunjungan wisatawan mengalami peningkatan sebesar rata-rata $10 \%$ baik wisatawan domestik maupun wisatawan macanegara. Daya tarik yang dimiliki oleh Yogyakarta ada pada beragamnya jenis kebudayaan yang ada, yaitu sekitar 4 ribu lebih, yang terdiri dari budaya fisik maupun non fisik. Budaya fisik (tangible) meliputi kawasan cagar budaya dan permuseuman yang tersebar di seluruh propinsi DI Yogyakarta, sedangkan budaya non fisik (intangible) meliputi kesenian dan upacara adat. 
Keanekaragaman budaya menjadi kebanggaan masyarakat dan menjadi nilai jual bagi wisatawan yang berkunjung ke suatu daerah tujuan wisata. Berdasarkan data tahun 2014, jumlah wisatawan mancanegara yang datang ke Indonesia sebesar 9,4 juta lebih atau tumbuh sebesar $7.05 \%$ dibandingkan tahun sebelumnya. (BPS, 2014). Menurut data dari Badan Pusat Statistik, sebelas provinsi yang paling sering dikunjungi oleh para turis adalah Bali sekitar lebih dari 3,7 juta disusul, DKI Jakarta, Daerah Istimewa Yogyakarta, Jawa Timur, Jawa Barat, Sumatera Utara, Lampung, Sulawesi Selatan, Sumatera Selatan, Banten dan Sumatera Barat.

Kekayaan yang berbasis budaya tradisional mempunyai nilai ekonomi yang sangat tinggi. Upaya perlindungan terhadap ekspresi budaya traadisional tentunya akan mendorong peningkatan perekonomian Indonesia dan dapat meningkatkan kesejahteraan masyarakat. (Wedhatami dan Santosa, 2014: 34)

Perjuangan Indonesia sebagai salah satu negara berkembang untuk adanya perlindungan hukum terus diselenggarakan untuk merumuskan sistem perlindungan yang tepat bagi Ekspresi Budaya Tradisional tersebut. Salah satunya dengan membuat RUU Pengetahuan Tradisional dan Ekspresi Budaya Tradisional (RUU PTEBT), yang hingga saat ini belum berhasil diundangkan sebagai undang-undang. Sementara keberadaan peraturan yang telah ada yaitu Undang-Undang Nomor 28 Tahun 2014 tentang Hak Cipta belum sepenuhnya dapat diberlakukan secara optimal, karena belum adanya peraturan pelaksanaannya hingga saat ini.

Dalam sistem hukum Hak Kekayaan Intelektual (HKI) di Indonesia, pengaturan terhadap budaya-budaya tradisional tersebut diatur dalam Undang-undang Nomor 28 Tahun 2014 Tentang Hak Cipta. Dalam Undang-undang tersebut pengaturan mengenai budaya tradisional terdapat dalam Bab $\mathrm{V}$ Tentang Ekspresi Budaya Tradisional dan Ciptaan Yang Dilindungi, khususnya dalam Pasal 38.

Terhadap Ekspresi Budaya Tradisional tersebut negara diberikan kewajiban yang dimuat dalam Pasal 38 ayat (2), yaitu kewajiban negara terhadap pemeliharaan dan pengelolaan budaya tradisional. Secara lengkap yang disampaikan dalam pasal tersebut adalah "Negara wajib menginventarisasi, menjaga, memelihara Ekspresi Budaya Tradisional sebagaimana dimaksud pada ayat (1)". Adanya kewajiban negara terhadap segala bentuk Ekspresi Budaya Tradisional dalam Undang-undang Hak Cipta Nomor 28 Tahun 2014 sudah disebutkan secara eksplisit. Negara sebagai pihak pemilik budaya tradisional (dalam hal ini pemerintah daerah setempat) memiliki kewajiban dalam rangka pemeliharaan dan pengelolaan budaya tersebut, antara lain kewajiban untuk melakukan inventarisasi budaya, menjaga dan memelihara budaya dari segala bentuk pelanggaran maupun pemanfaatan budaya tradisional tanpa hak yang sah. Hanya saja ketentuan yang ditegaskan dalam undang-undang tersebut sampai dengan saat ini belum bisa dilaksanakan karena berbagai kendala, antara lain peraturan teknis pelaksananya dan juga karena faktor sumber daya manusianya.

Konsep-konsep cakupan perlindungan Ekspresi Budaya Tradisional sangat erat kaitannya dengan daerah sebagai "pengemban" budaya tradisional, sehingga pemerintah daerah, baik provinsi maupun kabupaten/kota memegang tugas dan fungsi penting dalamperlindungan dan pemanfaatannya.

Saat ini di Yogyakarta belum terdapat suatu peraturan yang secara teknis dan kongrit mengatur mengenai perlindungan bagi berbagai macam budaya di Yogyakarta (Asri, 2012: 37). Selama ini peran Dinas Pariwisata dan Budaya Kota Yogyakarta sebagai lembaga di daerah yang mengelola berbagai kebudayaan tradisional, belum menunjukan peran yang efektif terkait kewajiban seperti yang tertuang dalam Pasal 38 ayat (2) Undang-undang Hak Cipta. Hal ini disebabkan oleh beberapa faktor diantaranya belum terdapatnya ketentuan mengenai pelaksanaan teknis untuk melakukan kegiatan inventarisasi dan dokumentasi terhadap budaya lokal tersebut. (Asri, 2014:150). Di sisi lain hal tersebut merupakan kebutuhan yang mendesak, agar setiap daerah dapat mempublikasikan terkait dengan budaya lokal yang sudah terinventarisasikan dengan baik dan terdokumentasikan secara sistematis.

Konsep perlindungan hukum terhadap Ekspresi Budaya Tradisional berbeda seperti halnya perlindungan hukum terhadap obyek hak cipta lainnya seperti yang terdapat dalam Undang-undang Nomor 2018 Tahun 2014 Tentang Hak Cipta. Pencatatan Hak Cipta sebagaimana yang ada dalam Undang-undang tersebut mengharuskan dilakukan dengan pencantuman nama pencipta, sebagai pihak yang akan diberikan perlindungan hukumnya, sekalipun prinsip pencatatan tersebut bukan 
merupakan suatu kewajiban. Namun jika berbicara mengenai ekspresi budaya tradisional yang merupakan bagian dari karya cipta, jika pencatatannya dilakukan maka yang menjadi pemegang hak cipta ada Negara sesuai yang diamanatkan dalam Pasal 38 ayat (2) Undang-undang Hak Cipta. Hal ini disebabkan karena pencipta terhadap ekspresi kebudayaan tradisional tidak lagi diketahui. Kewajiban yang harus dilakukan oleh negara sebagai pemegang Hak Cipta atas ekspresi kebudayaan tradisioanal adalah melakukan inventarisasi dan dokumentasi kebudayaan tersebut.

Adanya ketentuan kewajiban Negara terhadap ekspresi budaya tradisional sesuai yang ada pada Pasal 38 Undang-undang Nomor 28 Tahun 2014, menunjukan pentingnya perlindungan terhadap ekspresi budaya tradisional, yang merupakan aset yang sangat berharga dari pemerintah. Terkait banyaknya pelanggaran pemanfaatan dan klaim kebudayaan yang terjadi beberapa waktu yang lalu oleh Malaysia, membuktikan bahwa ancaman terhadap pelanggaran pemanfaatan maupun klaim kebudayaan sangat berpotensi terjadi terlebih Indonesia sebagai negara yang memiliki beragam jenis kebudayaan.

Sekalipun pelanggaran terhadap budaya-budaya yang ada di Yogyakarta memang belum nampak, seperti klaim dari negara lain terhadap budaya di Yogyakarta, hal ini tidak berarti dikemudian hari budaya Yogyakarta aman dari klaim kebudayaan oleh negara lain. Potensi terhadap pelanggaran klaim budaya di Yogyakarta akan selalu ada, dikarenakan daya tarik Yogyakarta ada pada wisata budayanya, sehingga akan menimbulkan potensi adanya klaim terhadap berbagai macam budaya yang menjadi aset daerah. Hal inilah yang menjadi alasan pentingnya menjaga nilai-nilai budaya di Yogyakarta dalam melestarikan dan melindungi budaya di Yogyakarta dari berbagai bentuk pelanggarannya. Sikap proteksi dan preventif terhadap pemeliharaan budaya di Yogyakarta tentunya akan lebih baik demi menjaga kelestarian budaya milik masyarakat adat di DIY.

Pemberian perlindungan bagi Ekspresi Budaya Tradisional menjadi penting ketika dihadapkan pada karakteristik dan keunikan yang dimilikinya dan juga berperan positif memberikan dukungan kepada komunitas masyarakat hukum adat selaku pemilik dan pengemban kebudayaan tersebut untuk melestarikan tradisinya. Agar kepemilikannya tidak diakui tanpa izin oleh negara lain. Oleh sebab itu kekayaan budaya tersebut perlu memperoleh perlindungan hukum. Apalagi diketahui jelas, bahwa semua kekayaan yang berbasis budaya tradisional mempunyai nilai ekonomi yang sangat tinggi. Upaya tersebut tentunya akan mendorong peningkatan perekonomian Indonesia dan dapat meningkatkan kesejahteraan masyarakat.

Berdasarkan latar belakang permasalahan di atas maka dapat disusun rumusan permasalahan sebagai berikut:

1. Bagaimanakah konsep perlindungan hukum terhadap ekspresi budaya tradisional yang memberikan perlindungan untuk menjaga klaim kepemilikan kebudayaan tersebut?

2. Bagaimanakah perlindungan hukum terhadap ekspresi budaya tradisional di Daerah Istimewa Yogyakarta selama ini ?

\section{METODOLOGI PENELITIAN}

\section{Jenis Penelitian}

Penelitian ini merupakan penelitian yuridis normatif.Penelitian yuridis normatif ini dilakukan dengan cara menelaah dan meng-interpretasikan halhal yang bersifat teoritis yang menyangkut asas, konsepsi, doktrin dan norma hukum yang berkaitan dengan pengaturan kearifan lokal dan budaya tradisional dalam peraturan Hak Kekayaan Intelektual.

\section{Sumber Data}

Sumber data yang dipakai dalam penelitian ini menggunakan data primer, yaitu data yang diperoleh dari lapangan melalui observasi, wawancara, maupun data yang diperoleh dari sumber-sumber yang terpercaya, yang diolah oleh peneliti. Observasi, wawancara dan pengumpulan data di lapangan dapat diperoleh dari para narasumber yang telah ditentukan dalam penelitian ini. Wawancara dilakukan secara terstruktur dan tidak terstruktur. Wawancara terstruktur berpedoman kepada pedoman wawancara yang telah disiapkan dan dilakukan terhadap narasumber, yaitu :

1. Kepala Kantor Kementerian Hukum dan Hak Asasi Manusia Kantor Wilayah DIY cq Kepala Bidang Pelayanan Hak Kekayaan Intelektual;

2. Kepala Dinas Pariwisata dan Kebudayaan Kota Yogyakarta,;

3. Kepala Dinas Budaya dan Pariwisata Kabupaten Sleman. 
Selain itu ada sumber data sekunder dalam penelitian ini berupa data yang di ambil dari bahan pustaka yang terdiri dari 3 (tiga) sumber bahan hukum yaitu bahan hukum primer, sekunder dan tersier.

\section{Analisis Data}

Analisis data dalam penelitian ini menggunakan analisis kualitatif, artinya menguraikan data yang diolah secara rinci kedalam bentuk kalimat-kalimat (deskriptif). Analisis kualitatifyang dilakukan bertitik tolak dari analisis empiris, yang dalam pendalamannya dilengkapi dengan analisis normatif. Berdasarkan hasil analisis ditarik kesimpulan secara dedukatif, yaitu cara berpikir yang didasarkan pada fakta-fakta yang bersifat umum untuk kemudian ditarik suatu kesimpulan bersifat khusus.

\section{HASIL DAN PEMBAHASAN}

\section{Perlindungan Hukum Terhadap Ekspresi Budaya Tradisional Yang Memberikan Perlindungan Untuk Menjaga Klaim Kepemilikan Kebudayaan}

Sebelum membicarakan mengenai perlindungan hukum Ekspresi Budaya Tradisional, terlebih dahulu akan dibahas konsep tentang perlindungan hukum secara umum, yang merujuk pada pendapat para ahli hukum.

Perlindungan hukum adalah memberikan pengayoman kepada hak asasi manusia yang dirugikan orang lain dan perlindungan tersebut diberikan kepada masyarakat agar mereka dapat menikmati semua hak-hak yang diberikan oleh hukum atau dengan kata lain perlindungan hukum adalah berbagai upaya hukum yang harus diberikan oleh aparat penegak hukum untuk memberikan rasa aman, baik secara pikiran maupun fisik dari gangguan dan berbagai ancaman dari pihak manapun. (Rahardjo,1993:74)

Menurut pendapat Phillipus M. Hadjon bahwa perlindungan hukum bagi rakyat sebagai tindakan pemerintah yang bersifat preventif dan represif. Perlindungan hukum yang preventif bertujuan untuk mencegah terjadinya sengketa, yang mengarahkan tindakan pemerintah bersikap hati-hati dalam pengambilan keputusan berdasarkan diskresi, dan perlindungan yang represif bertujuan untuk menyelesaikan terjadinya sengketa, termasuk penanganannya di lembaga peradilan (Hadjon 1987:29).
Pengaturan mengenai Ekspresi Budaya Tradisional di Indonesia terkait juga sebagai upaya pemerintah untuk memberikan perlindungan hukum terhadap pihak-pihak yang memiliki kepentingan/kepemilikan atas Ekspresi Budaya Tradisional. Perlindungan atas Ekspresi Budaya Tradisional diatur dalam Undangundang Nomor 28 Tahun 2014 Tentang Hak Cipta. Sekalipun dulu pernah dibuat rancangan kebijakan hukum yang mengatur mengenai ekspresi budaya tradisional di Indonesia dalam bentuk Rancangan Undang-undang Mengenai Pengetahuan Tradisional dan Ekspresi Budaya Tradisional (RUU PTEBT) namun hingga saat ini belum diundangkan.

Definisi Hak Cipta dalam Pasal 1 angka 1 UndangUndang Nomor 28 Tahun 2014 tentang Hak Cipta berbunyi: "Hak Cipta yaitu hak eksklusif pencipta yang timbul secara otomatis berdasarkan prinsip deklaratif setelah suatu ciptaan diwujudkan dalam bentuk nyata tanpa mengurangi pembatasan sesuai dengan ketentuan peraturan perundang-undangan."

Di dalam Undang-undang Nomor 28 Tahun 2014 tentang Hak Cipta, juga mengatur mengenai Ekspresi Budaya Tradisional. Dapat dilihat dalam pasal 38 Ayat (1), (2), (3) dan (4) Undang-Undang Hak Cipta, secara berturut-turut akan disampaikan sebagai berikut:

(1) Hak Cipta atas Ekspresi Budaya Tradisional dipegang olehNegara

(2) Negara wajib menginventarisasi, menjaga, dan memelihara Ekspresi Budaya Tradisional sebagaimana dimaksud padaayat (1).

(3) Penggunaan Ekspresi Budaya Tradisional sebagaimana dimaksud pada ayat (1) harus memperhatikan nilai-nilaiyang hidup dalam masyarakat pengembannya.

(4) Ketentuan lebih lanjut mengenai Hak Cipta yang dipegangoleh Negara atas Ekspresi Budaya Tradisional sebagaimanadimaksud pada ayat (1) diatur dengan PeraturanPemerintah.

Ekspresi Budaya Tradisional menurut penjelasan Pasal 38 ayat 1 Undang-undang No 28 Tahun 2014 adalah yang mencakup salah satu atau kombinasi bentuk ekspresi sebagai berikut:

1. Verbal tekstual, baik lisan maupun tulisan, yang berbentuk prosa maupun puisi, dalam berbagai tema dan kandungan isi pesan, yang berbentuk karya sastra ataupun narasi informatif;

2. Musik, mencakup antara lain, vokal, instrumental, atau kombinasinya;

3. Gerak, mencakup antara lain, tarian; 
4. Teater, mencakup antara lain, pertunjukan wayang dan sandiwara rakyat;

5. Seni rupa, baik bentuk dua dimensi maupun tiga dimensi yang terbuat dari, berbagai macam bahan seperti kulit, kayu, bambu, logam, batu, keramik, kertas, tekstil, dan lain-lain atau kombinasinya; dan

6. Upacara adat

Negara sebagai pemegang Hak Cipta Ekspresi Budaya Tradisional memperoleh Hak Eksklusif atas Karya Cipta tersebut. Hak-hak eksklusif yang diatur dalam Undang-undang Hak Cipta adalah hak untuk menerbitkan, menggandakan, menerjemahkan, mengadaptasi, mentransformasi, mendistribusikan, mempertunjukkan dan mengumumkan.

Negara sebagai otoritas tertinggi, dan pemerintah daerah sebagai representasi negara dalam perlindungan dan pengaturan Ekspresi Budaya Tradisional dapat mencegah adanya monopoli atau komersialisasi serta tindakan yang merusak ataupemanfaatan komersialisasi oleh pihak asing tanpa seizin negara sebagaipemegang Hak Cipta. Hanya saja sampai saat ini belum ada Peraturan Pemerintah yang mengatur lebih lanjut tentang hak cipta yang dipegang oleh Negara. (Perangin-angin, 2017:65)

Ciptaan yang tergolong ke dalam Ekspresi Budaya Tradisionaldapat dilihat dari Pasal 60 ayat (1) Undang-Undang Nomor 28 Tahun 2014 yang berisi: Hak Cipta atas Ekspresi Budaya Tradisional yang dipegang oleh negara sebagaimana dimaksud Pasal 38 ayat (1) berlaku tanpa batas waktu. Pasal ini jelas bertujuan melindungi karya-karya tradisional. Walaupun demikian, meskipun tujuan dari pasal 60 ini adalah untuk melindungi karya-karya intelektual berupa budaya, adat istiadat dan maupun nilai-nilai budaya yang terkandung dalam masyarakat asli, akan sulit bagi masyarakat tradisional untuk menggunakannya demi melindungi karya-karya intelektual tersebut.

Di satu sisi pada kenyataannya belum ada usaha dari negara dalam rangka melindungi karya-karya tradisional yang dieksploitasi oleh negara lain atau pihak lain sebagai pihak asing yang tidak memiliki hak untuk mengeksploitasi.

Pada tingkatan paling tinggi dari hubungan kepemilikan, hukum bertindak lebih jauh, dan menjamin bagi setiap manusia atas penguasaan dan penikmatan eksklusif terhadap benda atau ciptaannya tersebut dengan bantuan Negara. Gambaran tersebut menunjukkan bahwa perlindungan hukum adalah untuk kepentingan si pemilik, baik pribadi maupun kelompok yang merupakan subjek hukum, meskipun saat ini perkembangan hukum Hak Kekayaan Intelektual menyeimbangkan antara kepentingan pemilik hak dan masyarakat umum.

Alasan yang paling mendasar untuk perlindungan atas karya intelektual berwujud Hak Cipta khususnya adalah bahwa seseorang yang telah mengeluarkan usaha untuk meciptakan sesuatu karya cipta memiliki sebuah hak alami untuk memiliki dan mengontrol apa yang telah mereka ciptakan. Pendekatan ini menekankan pada kejujuran dan keadilan.

Perlindungan Ekspresi Budaya Tradisional melalui hukum hak cipta merupakan salah satu bentuk perlindungan yang paling relevan dalam prinsipprinsip hukum Kekayaan Intelektual. Walaupun demikian perlindungan melalui hukum cipta bukan berarti tidak menemui masalah ketika persyaratan dan prinsip-prinsip perlindungan Hak Cipta akan diterapkan, seperti bentuk karya berwujud (fixation work), keaslian (originality), pencipta teridentifikasi (identication of author) dan jangka yang dibatasi. Persyaratan bentuk karya berwujud (fixation) dalam hukum cipta merupakan salah satu peryaratan yang harus dipenuhi bilamana suatu karya berhak untuk mendapatkan perlindungan hukum.

Persyaratan karya harus berwujud dalam bentuk materi ini akan menjadi hambatan apabila diterapkan pada perlindungan Ekspresi Budaya Tradisional karena hampir sebagaian besar karya yang berbasis budaya tradisional mempunyai karakter oral tranmisi (tidak tertulis) seperti sebagian besar dongeng, legenda, mitos, tarian dan lagu rakyat atau dengan kata lain rezim hukum cipta tidak bisa melindungi secara menyeluruh terhadap karya-karya Ekspresi Budaya Tradisional terebut, kecuali untuk kategori Ekspresi Budaya Tradisional non lisan. Padahal kenyataannya kreasi-kreasi yang masih menggunakan tradisi oral tersebut masih eksis dan hidup di masyarakat tradisional.

Perbedaan karakter antara Hak Kekayaan Intelektual dan Ekspresi Budaya Tradisional membuat sistem hukum Kekayaan Intelektual kita tak cukup mampu melindungi secara utuh Ekspresi Budaya Tradisional. Secara karakter, walaupun sama-sama bersumber dari kreativitas intelektual manusia, di antara 
keduanya terdapat perbedaan mendasar. Gagasan Hak Kekayaan Intelektual diwujudkan dalam ekspresi nyata, dan itu perbedaan yang mendasar.

Pencipta Hak Kekayaan Intelektual teridentifikasi secara jelas dan orientasi ciptaan atau temuannya lebih ke arah motif ekonomi ketimbang ekspresi dari si pencipta atau penemu. Dalam Ekspresi Budaya Tradisional, identifikasi pencipta asli tidak diketahui karena komunitas masyarakat tradisional/lokal mencipta karya itu secara turun-temurun lintas generasi.

Permasalahan yang mendasar adalah bahwa nilainilai budaya masyarakat setempat tidak mengenal kepemilikan individu terhadap suatu karya cipta dalam bidang ilmu pengetahuan, sastra dan seni. Keadaan ini tampak jelas dalam penghargaan atas kreativitas dan karya seni dalam masyarakat tradisional. (Riswandi,2005:204)

Dalam konsep Hak Kekayaan Intelektual khususnya dalam Undang-undang Hak Cipta, pemberian perlindungan terhadap Ekspresi Budaya Tradisional berbeda dengan pemberian perlindungan pada jenis Hak Cipta lain seperti pada buku, karya musik maupun lukisan. Hal ini dikarenakan terhadap Ekspresi Budaya Tradisional tersebut kepemilikannya bukan bersifat individu seperti hanya pada karya cipta buku, musik atau lukisan tersebut. Namun kepemilikan Ekspresi Budaya Tradisional tersebut merupakan kepemilikan secara komunal. Artinya Ekspresi Budaya Tradisional dimiliki oleh sekelompok masyarakat adat pada suatu daerah atau tempat tertentu, sehingga untuk diterapkan perlindungan hukum secara individu sangat sulit dilakukan.

Ekspresi budaya tradisional merupakan miliki bersama (komunal) suku bangsa pemiliknya. Tidak ada individu yang memiliki ekspresi budaya tradisional secara pribadi karena masyarakat secara bersama yang membuat ekspresi budaya tradisional tersebut hidup (Weeraworawit, 2003: 769) Perlindungan terhadap Ekspresi Budaya Tradisional, dengan melihat pada kenyataan dan ciri-ciri yang melekat pada Ekspresi Budaya Tradisional diatas, yang sangat berbeda dengan rezim Hak Kekayaan Intelektual umumnya seperti Hak Cipta lagu, merek, paten yang sangat bersifat invidividualistik. Sehingga pengaturan mengenai komponen perlindungan yang tepat untuk diberlakukan pada Ekspresi Budaya Tradisional perlu dibedakan dengan jenis Hak
Kekayaan Intelektual umumnya. Sehingga diperlukan upaya perlindungan yang bersifat preventif dan represif.

Dalam menjalankan dan memberikan perlindungan hukum dibutuhkannya suatu tempat atau wadah dalam pelaksanaannya yang sering disebut dengan sarana perlindungan hukum, sarana perlindungan hukum dibagi menjadi dua macam yang dapat dipahami, sebagai berikut : (Muchsin,2003:20)

\section{Perlindungan Hukum Preventif.}

Perlindungan yang diberikan oleh pemerintah dengan tujuan untuk mencegah sebelum terjadinya pelanggaran. Hal ini terdapat dalam peraturan perundang-undangan dengan maksud untuk mencegah suatu pelanggaran serta memberikan rambu-rambu atau batasan-batasan dalam melakukan sutu kewajiban.

\section{Perlindungan Hukum Represif.}

Perlindungan hukum represif merupakan perlindungan akhir berupa sanksi seperti denda, penjara, dan hukuman tambahan yang diberikan apabila sudah terjadi sengketa atau telah dilakukan suatu pelanggaran.

Perlindungan Preventif dari Ekspresi Budaya Tradisional di Indonesia terdapat dalam Undangundang Nomor 28 Tahun 2014 tentang Hak Cipta, dimana diatur mengenai ketentuan tentang Ekspresi Budaya Tradisional, khususnya pada Pasal 38. Negara sebagai pemegang Hak Cipta atas ekspresi budaya tradisonal, mengatur terhadap aspek perlindungan dari Ekspresi Budaya Tradisional tersebut dengan melakukan kewajiban-kewajiban yang melekat pada negara untuk menginventarisasi, menjaga, dan memelihara terhadap berbagai macam Ekspresi Budaya Tradisional di Indonesia.

Dalam penelitian yang dilakukan di lapangan, melihat fenomena terhadap perlindungan Hak Kekayaan Intelektual terhadap Ekspresi Budaya Tradisional tersebut, khususnya perlindungan Preventif, bahwa selain terdapat Undang-undang Hak Cipta sebagai norma hukum yang dibuat dalam rangka memberikan kepastian hukum, juga terdapat upaya preventif yang dilakukan oleh Dinas Kebudayaan maupun Dinas Kebudayaan dan Pariwisata di Kota Yogyakarta dan di Kabupaten Sleman, bahwa selama ini mereka telah melakukan kegiatan yang berupa inventarisasi dan dokumentasi terhadap sejumlah kebudayaan yang tersebar di wilayah tersebut. Meskipun kegiatan 
tersebut dilakukan belum secara menyeluruh dan belum terkoordinasi dengan baik antar pihak terkait, sehingga hasilnya pun belum optimal dan terukur.

Saat ini di DI Yogyakarta belum adanya suatu peraturan daerah yang mengatur mengenai Hak Cipta dan perlindungan bagi budaya tardisional, sehingga para pelaku budaya maupun masyarakat adat merasa hak-hak mereka terhadap karya cipta yang telah mereka hasilkan dan pelihara selama bertahun-tahun lamanya tidak dilindungi secara hukum. (Hasil wawancara, 19 Juni 2015)

Salah satu perangkat hukum yang penting adalah basis data (database) yang akurat tentang Pengetahuan Tradisional, Ekspresi Budaya Tradisional, dan sumber daya hayati Indonesia, yang nantinya akan sangat diperlukan dalam rangka melakukan klaim terhadap pihak luar yang dianggap melanggar hak-hak masyarakat lokal di Indonesia. Tentu saja untuk menyusun basis data semacam itu bukanlah pekerjaan yang mudah dan murah. Oleh karena itu, perlu dipikirkan sistem pengembangan basis data yang relatif mudah dan murah. Untuk itu, harus dikembangkan dan diuji coba sistem yang bersifat partisipatif. Di sinilah peran para ahli teknologi informasi dapat dilibatkan. Untuk uploading data bisa dilakukan siapa saja, baik instansi pemerintah dari setiap sektor, maupun lembaga swadaya masyarakat (LSM), atau warga masyarakat pada umumnya yang memiliki data atau informasi tentang Pengetahuan Tradisional, Ekspresi Budaya Tradisional, dan sumber daya hayati Indonesia.

Oleh karena itu untuk melindungi warisan budaya Indonesia, tidak cukup bagi pemerintah hanya sekedar membuat aturan hukumnya saja, melainkan proses dokumentasi dan kompilasi data base budaya lokal maupun Pengetahuan Tradisional Indonesia adalah hal vital untuk aspek pelestarian budayanya sebagai pencegahan dari kepunahan. Apabila warisan budaya lokal tersebut punah karena tidak lagi dipraktekkan oleh komunitasnya, maka hilang juga perlindungan $\mathrm{HKI}$ atas budaya tersebut, dan sebagai akibatnya budaya tersebut akan menjadi public domain. Budaya Lokal dan Pengetahuan Tradisional dapat punah dalam arti bahwa komunitas atau masyarakat dari negara mana Budaya Lokal dan Pengetahuan Tradisional itu menjadi ciri kharakteristiknya, meninggalkan atau tidak lagi mempraktekkan budaya tersebut. Oleh karena itu budaya lokal tersebut kehilangan karakter 'tradisionalnya' yang melekat sebagai tradisi dari komunitas masyarakat atau negara yang mengemban sebelumnya. Database dan dokumentasi merupakan kunci untuk sukses melawan klaim HKI dari negara lain.

Rezim Hak Cipta sulit untuk diterapkan untuk melindungi folklor. (Sardjono, 2006: 88) Untuk itulah perlu dibentuknya suatu kerangka pengaturan tersendiri (sui generis) yang mengatur mengenai perlindungan terhadap Pengetahuan Tradisional dan Ekspresi Budaya Tradisional. Selain itu, perlu diciptakan pula pengaturan yang memberikan landasan hukum (legal standing) yang jelas bagi pihak-pihak yang akan melakukan tuntutan kepada pihak-pihak luar yang dianggap melakukan pengambilan secara melawan hak atas kekayaan warisan budaya tersebut.

Ekspresi Budaya Tradisional merupakan aspek yang tidak terpisahkan dalam pembentukan identitas suatu bangsa. Sayangnya, kepemilikan kolektif rakyat Indonesia terhadap Ekspresi Budaya Tradisional tidak dapat diakomodasi dengan logika Kekayaan Intelektual konvesional. (Ayu dkk, 2017: 206)

\section{Perlindungan Hukum Terhadap Ekspresi Budaya Tradisional di Daerah Istimewa Yogyakarta}

Indonesia adalah negara dengan kekayaan dan keragaman budaya serta tradisi yang luar biasa. Jika kekayaan keragaman budaya dan tradisi itu dapat dikelola dengan baik dan benar, maka bukan tidak mungkin kebangkitan ekonomi Indonesia justru dipicu bukan karena kecanggihan teknologi, melainkan karena keindahan tradisi dan keragaman warisan budaya itu sendiri.

Demikian pula dengan Daerah Istimewa Yogyakarta yang memiliki beragam budaya baik yang berwujud (tangible) maupun yang tidak berwujud (intangible). Keanekaragaman budaya tersebut tentunya menjadi kebanggaan masyarakat dan merupakan aset yang tidak ternilai bagi pemerintah daerah, karena menjadi nilai jual bagi wisatawan yang berkunjung ke Yogyakarta.

Dalam rangka pelestarian dan pengembangan kebudayaan di Indonesia, salah satu lembaga yang berperan dan mempunyai fungsi terhadap pengelolaan budaya tersebut adalah Kementerian Pendidikan dan Kebudayaan Republik Indonesia.

Kewenangan dari Kementerian Pendidikan dan Kebudayaan tersebut diatur dalam Peraturan Menteri 
Pendidikan dan Kebudayaan Republik Indonesia Nomor 11 Tahun 2015 Tentang Organisasi dan Tata Kerja Kementerian Pendidikan dan Kebudayaan.

Dalam Pasal 2 Peraturan Menteri Pendidikan dan Kebudayaan tersebut diatas, disebutkan mengenai tugas dari Kementerian Pendidikan dan Kebudayaan adalah menyelenggarakan urusan pemerintahan di bidang pendidikan anak usia dini, pendidikan dasar, pendidikan menengah, dan pendidikan masyarakat, serta pengelolaan kebudayaan untuk membantu Presiden dalam menyelenggarakan pemerintahan negara.

Pengelolaan terhadap budaya lokal yang merupakan kewenangan dari Kementerian ini merupakan tugas dan tanggung jawab dari Direktorat Kepercayaan Terhadap Tuhan Yang Maha Esa dan Tradisi.

Direktorat Jenderal Kebudayaan merupakan sebuah lembaga unsur pelaksana dari sebagian tugas pokok dan fungsi departemen yang berada di bawah dan bertanggung jawab kepada Menteri Pendidikan dan Kebudayaan. Tugas dari Direktorat Jenderal dan Kebudayaan adalah menyelenggarakan perumusan dan pelaksanaan kebijakan di bidang kebudayaan, kesenian, tradisi, sejarah, cagar budaya, permuseuman, warisan budaya, dan kebudayaan lainnya.

Mengenai pengelolaan dalam rangka perlindungan terhadap Ekspresi Budaya Tradisional yang menjadi tugas dari Subdit Pengetahuan dan Ekspresi Budaya Tradisional dalam hal ini Seksi Ekspresi Budaya Tradisional, mempunyai tugas melakukan penyusunan bahan perumusan, koordinasi, dan pelaksanaan kebijakan, norma, standar, prosedur, kriteria, bimbingan teknis dan supervisi, pembinaan dan pelestarian, evaluasi, dan laporan di bidang Ekspresi Budaya Tradisional. (Pasal 561 Ayat (2), Peraturan Menteri Pendidikan dan Kebudayaan Republik Indonesia Nomor 11 Tahun 2015 tentang Organisasi dan Tata Kerja Kementerian Pendidikan dan Kebudayaan)

Dalam ketentuan mengenai tugas dan fungsi pengelolaan kebudayaan khususnya budaya tak benda yang dalam peraturan ini disebut Warisan Budaya Tak Benda, dikelola oleh Subdirektorat Warisan Budaya Tak Benda yang mempunyai tugas melaksanakan penyusunan bahan perumusan, koordinasi, dan pelaksanaan kebijakan, norma, standar, prosedur, kriteria, bimbingan teknis dan supervisi, dan perlindungan Hak Kekayaan Intelektual (HKI) komunal di bidang penetapan, pengusulan, dan pengelolaan warisan budaya tak benda. Pengusulan tersebut diajukan kepada UNESCO sebagai warisan budaya dunia yang berasal dari Indonesia. Pentingnya pencatatan warisan budaya baik benda maupun tak benda, adalah untuk menghindari dari sesuatu yang tidak diinginkan seperti adanya klaim budaya dari pihak lain.

Salah satu cara perlindungan Ekspresi Budaya Tradisional adalah melalui pembentukan arsip dan dokumentasi nasional di tiap-tiap negara sehingga setiap orang dapat menemukan Ekspresi Budaya Tradisional yang terdapat di negara masing-masing. (Rafian dan Sabrina, 2014: 504). Pencatatan atas warisan budaya tak benda dianggap penting karena beberapa elemen terhadap warisan budaya tak benda mulai terancam punah. Kepunahan tersebut disebabkan oleh beberapa faktor baik faktor dari luar (eksternal) maupun dari dalam kebudayaan itu sendiri (internal).

Guna menghindari kepunahan warisan budaya tak benda di wilayah Indonesia, saat ini pemerintah mulai tanggap dan menetapkan perlindungan warisan budaya tak benda sejak tahun 2007 melalui Peraturan Presiden Nomor 78 Tahun 2007 Tentang Pengesahan Convention for The Safeguarding of the Intangible Cultural Heritage yakni Konvensi untuk perlindungan warisan budaya tak benda.

Hingga tahun 2016, 444 karya budaya tak benda telah terdaftar sebagai Warisan Budaya Tak Benda (WBTB) Indonesia yang dikelola oleh Direktorat Jenderal Kebudayaan, Kementerian Pendidikan dan Kebudayaan. Hal ini menandakan bahwa kinerja Kementerian Pendidikan dan Kebudayaan dalam rangka ikut mengelola dan melindungi tradisi budaya di Indonesia semakin nyata.

Berdasarkan hasil penelitian, Inventarisasi kebudayaan di Yogyakarta secara rinci belum dilakukan baik oleh Dinas Pariwisata dan Kebudayaan, Dinas Kebudayaan Propinsi DI Yogyakarta maupun oleh Balai Pelestarian Nilai Budaya. Selama ini invetarisasi banyak dilakukan khusus untuk inventerisasi budaya yang berwujud fisik bangunan yang sering disebut dengan bangunan cagar budaya. Seperti yang telah dilakukan oleh Badan Perencanaan Pembangunan Daerah Kota Yogyakarta yang menginventarisasi sejumlah bangunan cagar budaya di Yogyakarta. 
Adanya kecenderungan terhadap kenyataan belum terinventarisasi serta terdokumentasi berbagai macam budaya di Yogyakarta, terutama budaya yang intangible selama ini digambarkan dalam laporan hasil penelitian (DPB Asri,2012:30) yang menyatakan bahwa peran dari Dinas Kebudayaan dan Pariwisata baik di Kota Yogyakarta dan di Kabupaten Sleman dalam menginventarisasi dan mendokumentasikan berbagai macam budaya-budaya di Yogyakarta belum nampak. Hal tersebut dikarenakan berbagai faktor :

1. Terbatasnya sumber daya manusia baik pada sisi pengetahuan, pemahaman maupun keahliannya untuk dapat melakukan kegiatan tersebut

2. Belum adanya aturan dan kebijakan yang bersifat teknis tentang kewenangan pihak yang melakukan kegiatan tersebut

3. Kurang koordinasi antar berbagai lembaga terkait, sehingga kerjasama dalam memelihara berbagai kebudayaan di Yogyakarta belum berhasil dilaksanakan.

Upaya untuk melakukan kegiatan inventarisasi dan dokumentasi terhadap berbagai kebudayaan di Yogyakarta, sebenarnya merupakan kegiatan dalam rangka melindungi berbagai macam jenis budaya di Yogyakarta, dari punahnya maupun ancaman kepemilikan budaya tersebut oleh daerah maupun negara lain. Upaya ini juga sekaligus melaksanakan ketentuan dalam hukum Hak Kekayaan Intelektual dalam melakukan perlindungan terhadap Ekspresi Budaya Tradisional yaitu perlindungan Preventif.

Dengan adanya kegiatan inventarisasi dan dokumentasi tersebut, harapannya terhadap klaim kepemilikan budaya-budaya di Indonesia khususnya di Yogyakarta oleh negara lain akan dapat dihindari. Oleh karena itu, untuk melindungi ekspresi budaya tradisional tersebut yang dimiliki oleh Indonesia tidak hanya dengan memilik Undang-Undang sui generis saja. Dokumentasi dan database yang mendukung perlindungan terhadap ekspresi budaya tradisional juga diperlukan sebagai pendukung pelaksanaan Undang-Undang sui generis, tujuannya adalah untuk menjaga budaya Indonesia dari kepunahan. (Asri, 2016: 630)

Berkaitan dengan kepemilikan dan klaim-klaim budaya oleh pihak asing, Pemerintahan Daerah dalam hal ini Provinsi DI Yogyakarta sebagai penanggung jawab tunggal dalam penyelenggaraan pemerintahan di daerah, dalam menyelenggarakan otonomi daerah mempunyai kewajiban melestarikan dan melindungi nilai sosial budaya masyarakatnya serta dapat membentuk dan menerapkan peraturan perundangundangan sesuai dengan kewenangannya.

Peraturan perundang-undangan tentang otonomi daerah memang tidak secara langsung memberikan penjelasan tentang keterkaitan antara pemerintah daerah dengan sistem Hak Kekayaan Intelektual. Namun dalam hal ini perlu inisiatif dan kreatifitas Pemerintah Daerah untuk melindungi Ekspresi Budaya Tradisional masyarakatnya yang dikaitkan dengan Hak Kekayaan Intelektual khususnya Hak Cipta.

Retensi kedaulatan nasional diperlukan untuk melindungi ekspresi budaya tradisional dalam kualitas yang tepat, termasuk nilai-nilai ekonomi yang dapat digunakan oleh warga. (Setyaningtyas dan Kawuryan, 2016: 129). Dalam rangka pelestarian dan pengembangan kebudayaan di Indonesia, salah satu lembaga yang berperan dan mempunyai fungsi terhadap pengelolaan budaya tersebut adalah Kementerian Pendidikan dan Kebudayaan Republik Indonesia.

Kewenangan dari Kementerian Pendidikan dan Kebudayaan tersebut diatur dalam Peraturan Menteri Pendidikan dan Kebudayaan Republik Indonesia Nomor 11 Tahun 2015 Tentang Organisasi dan Tata Kerja Kementerian Pendidikan dan Kebudayaan.

Sejak tahun 2013, Dinas Kebudayaan DI Yogyakarta telah berupaya melakukan inventarisasi sejumlah kebudayaan di Yogyakarta. Tercatat ada 22 (duapuluh dua) karya budaya di Yogyakarta yang telah ditetapkan sebagai warisan budaya tak benda Indonesia. Menurut Dian Laksmi (Hasil Wawancara,19 April 2017) Budaya tersebut adalah:

1. Wayang Beber (2013);

2. Wayang Wong Mataraman (2013);

3. Wayang Kancil (2013);

4. Sekaten (2014);

5. Pawukon (2014);

6. Bedhaya Semang (2014);

7. Gamelan Gaya Yogyakarta (2014);

8. Kertas Daluang (2014);

9. Mubeng Beteng (2015);

10.Saparan Gamping/ Bekakak (2015);

11. Gudeg (2015);

12. Joglo Yogyakarta (2015);

13. Kerajinan Gebarah Kasongan (2015);

14. Suran Mbah Demang (2016);

15. Tawur Kesanga (2016); 
16. Labuhan Keraton (2016);

17.Jathilan Yogyakarta (2016);

18. Langendriyo (2016);

19. Tari Angguk (2016);

20. Langen Mandra Wanara (2016);

21. Bakpia Yogyakarta (2016);

22.Lurik Yogyakarta (2016).

Selain inventarisasi kebudayaan di Yogyakarta, selama ini Dinas Kebudayaan DI Yogyakarta, juga telah berupaya untuk memelihara keberadaan sejumlah kebudayaan tersebut dengan cara memberikan reward secara rutin kepada pelaku budaya melalui Penghargaan Anugerah Budaya baik kategori seniman, budayawan kelompok maupun lembaga adat, dengan memberikan insentif berupa uang penghargaan sebesar Rp. 25.000.000 (dua puluh lima juta) per orang/lembaga. (Hasil Wawancara, 19 April 2017)

\section{KESIMPULAN}

Perlindungan Ekspresi Budaya Tradisional melalui hukum hak cipta merupakan salah satu bentuk perlindungan yang paling relevan dalam prinsipprinsip hukum Kekayaan Intelektual. Walaupun demikian perlindungan melalui hukum cipta bukan berarti tidak menemui masalah ketika persyaratan dan prinsip-prinsip perlindungan Hak Cipta akan diterapkan, seperti bentuk karya berwujud (fixation work), keaslian (originality), pencipta teridentifikasi (identication of author) dan jangka yang dibatasi. Persyaratan bentuk karya berwujud (fixation) dalam hukum cipta merupakan salah satu peryaratan yang harus dipenuhi bilamana suatu karya berhak untuk mendapatkan perlindungan hukum.Perbedaan karakter antara Hak Kekayaan Intelektual dan Ekspresi Budaya Tradisional membuat sistem hukum Kekayaan Intelektual kita tak cukup mampu melindungi secara utuh Ekspresi Budaya Tradisional. Secara karakter, walaupun sama-sama bersumber dari kreativitas intelektual manusia, di antara keduanya terdapat perbedaan mendasar. Gagasan Hak Kekayaan Intelektual diwujudkan dalam ekspresi nyata, dan itu perbedaan yang mendasar. Perlindungan Preventif dari Ekspresi Budaya Tradisional di Indonesia terdapat dalam Undangundang Nomor 28 Tahun 2014 tentang Hak Cipta, dimana diatur mengenai ketentuan tentang Ekspresi Budaya Tradisional, khususnya pada Pasal 38. Negara sebagai pemegang Hak Cipta atas ekspresi budaya tradisonal, mengatur terhadap aspek perlindungan dari Ekspresi Budaya Tradisional tersebut dengan melakukan kewajiban-kewajiban yang melekat pada negara untuk menginventarisasi, menjaga, dan memelihara terhadap berbagai macam Ekspresi Budaya Tradisional di Indonesia.

Dalam penelitian yang dilakukan di lapangan, melihat fenomena terhadap perlindungan Hak Kekayaan Intelektual terhadap Ekspresi Budaya Tradisional tersebut, khususnya perlindungan Preventif, bahwa selain terdapat Undang-undang Hak Cipta sebagai norma hukum yang dibuat dalam rangka memberikan kepastian hukum, juga terdapat upaya preventif yang dilakukan oleh Dinas Kebudayaan maupun Dinas Kebudayaan dan Pariwisata di Kota Yogyakarta dan di Kabupaten Sleman, bahwa selama ini mereka telah melakukan kegiatan yang berupa inventarisasi dan dokumentasi terhadap sejumlah kebudayaan yang tersebar di wilayah tersebut. Meskipun kegiatan tersebut dilakukan belum secara menyeluruh dan belum terkoordinasi dengan baik antar pihak terkait, sehingga hasilnya pun belum optimal dan terukur.

Perlindungan hukum terhadap Ekspresi Budaya Tradisional di Yogyakarta selama ini dilakukan oleh Dinas Kebudayaan, Dinas Pariwisata dan Budaya serta Kementerian Hukum dan HAM Kanwil DIY. Dari ketiga lembaga tersebut, memang ada yang sudah melaksanakan sejumlah kegiatan seperti mendokumentasikan dan menginventarisasi kebudayaan yang merupakan perlindungan hukum preventif, terhadap beberapa kebudayaankebudayaan di Yogyakarta, seperti yang dilakukan oleh Dinas Kebudayaan Propinsi DI Yogyakarta dan Dinas Kebudayaan dan Pariwisata Kabupaten Sleman yang telah memulai melakukan inventarisasi sejumlah kebudayaan yang berasal dari Sleman maupun dari DI Yogyakarta, meski belum dilakukan secara menyeluruh, namun peran lembaga-lembaga tersebut sudah menunjukan kegiatan-kegiatan sesuai dengan aturan yang ada dalam Undang-undang Hak Cipta. Untuk kegiatan inventarisasi yang dilakukan Dinas Kebudayaan Propinsi DI Yogyakarta tercatat 22 kebudayaan tak berwujud (intangible) yang terdata dan untuk kegiatan inventarisasi yang dilakukan oleh Dinas Budaya dan Pariwisata Kabupaten Sleman ada 60 budaya intangible yang terdiri dari 10 upacara adat dan 50 tradisi budaya. Data-data tersebut membuktikan bahwa Ekspresi Budaya Tradisional di DIY telah didata sebagai budaya yang berasal dari Yogyakarta mengingat telah terdokumentasi dan telah diinventarisasi. Namun untuk Kementerian Hukum dan HAM yang beberapa waktu lalu telah 
melaksanakan kegiatan inventarisasi terhadap sejumlah kebudayaan di DIY, hingga saat ini tidak memiliki data serta tidak ada koordinasi antara lembaga terhadap kebijakan inventarisasi dan dokumentasi kebudayaan di Yogyakarta. Upaya inventarisasi dan dokumentasi kebudayaan sebagai wujud perlindungan dan pengelolaan Ekspresi Budaya Tradisional, tentunya harus dipahami bahwa kegiatan tersebut menjadi sangat penting, dikarenakan harapannya sejumlah daerah memiliki database kekayaan budayanya yang dengan sendirinya berarti dapat melindungi kebudayaan tersebut dari kepunahan maupun klaim dari pihak asing.

\section{SARAN}

Pemerintah Propinsi DI Yogyakarta perlu membuat regulasi dalam bentuk Peraturan Daerah dalam rangka mengelola dan mendokumentasikan kebudayaan di Yogyakarta sehingga dengan keberadaan Peraturan Daerah tersebut dapat segera ditindaklanjuti proses pendataan, pendokumentasian dan inventarisasi sehingga diharapkan kedepan dapat memberikan perlindungan, pemanfaatan dan pelestarian terhadap Ekspresi Budaya Tradisional dan kearifan lokal masyarakat adat yang ada di propinsi DI Yogyakarta.

Perlu dibuat model perlindungan preventif terhadap Ekspresi Budaya Tradisional dengan sistem database kebudayaan tak benda (intangible culture) di Yogyakarta dengan memanfaatkan kebijakan di tingkat daerah.

\section{DAFTAR PUSTAKA}

Asri, D. P. B. (2016). Implementasi Pasal 38 ayat (1) Undang-Undang Nomor 28 Tahun 2014 terhadap Ekspresi Budaya Tradisional di Kabupaten Sleman. Jurnal Hukum IUS QUIA IUSTUM, 23, (4).

(2014). Model Kebijakan Strategis Terhadap Pelestarian Kebudayaan Lokal "Merti Code" Sebagai Aset Daerah Untuk Meningkatkan Sektor Pariwisata Berbasis Budaya. Jurnal Hasil Penelitian Bappeda Pemerintahan Kota, 1.

(2012). Perlindungan Hukum Traditional Knowledge dalam Rangka Perlindungan Budaya Lokal di Kotagede Untuk Meningkatkan Pariwisata. Hasil Penelitian Pemerintahan Kota Yogyakarta.
Ayu, Miranda Risang., Permata, Rika Ratna., \& Rafianti, Laina. (2017). Sistem Perlindungan Sumber Daya Budaya Tak Benda di Palembang, Sumatera Selatan, Indonesia. Jurnal Mimbar Hukum, 29, 2.

Badan Pusat Statisik (BPS) Nasional Tahun 2014, diakses tanggal 7 Mei 2015

Hadjon, Phillipus M. (1987). Perlindungan Hukum Bagi Rakyat Indonesia. Surabaya: PT. Bina Ilmu.

Muchsin. (2003). Perlindungan dan Kepastian Hukum Bagi Investor di Indonesia, Surakarta. Tesis Magister Ilmu Hukum Program Pascasarjana Universitas Sebelas Maret.

Perangin-angin, Reh Bungana Beru. (2017). Prosiding Seminar Nasional Tahunan Fakultas Ilmu Sosial Universitas Negeri Medan. e-ISSN: 2549-5976 p-ISSN: 2549-435X.

Rafian, Laina., \& Sabrina, Qoliqina Zolla. (2014). Perlindungan bagi 'Kustodian' Ekspresi Budaya Tradisional Nadran Menurut Hukum Internasional danImplementasinya dalam Hukum Hak Kekayaan Intelektual di Indonesia. Padjadjaran Jurnal Ilmu Hukum (PJIH), 1, 3.

Rahardjo, Satjipto. (1993). Penyelenggaraan Keadilan dalam Masyarakat yang Sedang Berubah. Jurnal Masalah Hukum.

Riswandi, Budi Agus., \& Syamsudin, M. (2005). Hak Kekayaan Intelektual dan Budaya Hukum. Jakarta: Raja Grafindo Persada

Sardjono, Agus. (2006). Hak Kekayaan Intelektual \& Pengetahuan Tradisional. Bandung: PT. Alumni.

Setyaningtyas, Ayu Citra dan Kawuryan, Endang Sri. (2016). Menjaga Ekspresi Budaya Tradisional di Indonesia. Jurnal Ilmu Hukum Tambun Bungai, 1, 1.

Wedhatami, Bayangsari dan Santoso, Budi. (2014). Upaya Perlindungan Ekspresi Budaya Tradisional Dengan Pembentukan Peraturan Daerah. Jurnal Law Reform, 9, 2.

Weerawit, Weeraworawit. (2003). Formulating an International Legal Protection for Genetic Resources, Traditional Knowledge and Folklore: Challenges for The Intellectual Pro-pertysystem. Journal of International and Comparative Law, 769-783. 